\title{
Pandemi Sırasında Ebeveynlerin Uzaktan Eğitim Deneyimlerinin Değerlendirilmesi
}

\author{
Alev ÜSTÜNDAĞ \\ Sağlık Bilimleri Üniversitesi \\ alev.ustundag@sbu.edu.tr \\ ORCID: 0000-0001-5832-6810
}

\begin{tabular}{lrr} 
Araştırma Makalesi & DOI: $10.31592 /$ aeusbed.911791 \\
\hline Geliş Tarihi: 08.04.2021 & Revize Tarihi: 14.07 .2021 & Kabul Tarihi: 07.07 .2021
\end{tabular}

\section{Atıf Bilgisi}

Üstündağ, A. (2021). Pandemi sırasında ebeveynlerin uzaktan eğitim deneyimlerinin değerlendirilmesi. Ahi Evran Üniversitesi Sosyal Bilimler Enstitüsü Dergisi, 7 (2), 572-589.

\section{ÖZ}

Yeni Koronavirüs Hastalığının yayılmasının önlenebilmesi için alınan okulların kapatılması tedbiri, ülkemizde ilk kez uzaktan eğitim sürecinin başlamasına sebep olmuştur. Hem öğretmenler hem öğrenciler hem de ebeveynler için yeni olan bu süreç farklı deneyimler yaşanmasını sağlamıştır. Araştırmada pandemi sürecinde ebeveynlerin uzaktan eğitim deneyimlerinin değerlendirilmesi amacıyla yapılmıştır. Araştırma nitel araştırma deseniyle oluşturulmuş ve görüşme tekniği kullanılarak gerçekleştirilmiştir. Araştırmanın çalışma grubunda 21 ebeveyn bulunmaktadır. Araştırma verileri yapılandırılmış görüşme formu kullanılarak elde edilmiştir. Araştırma verilerinin analizinde betimsel analiz kullanılmıştır. Elde edilen sonuçlara göre araştırmaya katılan ebeveynlerin çoğunluğu okulların kapatılması kararını onaylamakla birlikte örgün eğitime geçilmesini istemektedir. Ebeveynlerin çocuklarının eğitimi için gün içerisinde vakit ayırdıkları, yeterli eğitim kaynağına sahip oldukları ve okulun sağladığı destekten memnun oldukları belirlenmiştir. Ancak uzaktan eğitim sürecinde teknik, sosyal, öğrenci merkezli ve eğitim merkezli zorluklar yaşadıkları ve öğretmenlerin süreçte anlayışlı davranarak destek olabileceklerini düşündükleri de belirlenmiştir. Sonuç olarak, uzaktan eğitim tüm ebeveynler için yeni bir durum olduğu için, ebeveynler ihtiyaç duymasalar bile, öğretmenler tarafindan desteklenmelerinin önemli olduğu düşünülmektedir. Ebeveynlerin öğretmenlerin bilgilendirmesine ve yol göstermesine olan ihtiyaçları bu süreçte çocuklarını destekleyebilmeleri için de motivasyon sağlayabilecektir.

Anahtar Kelimeler: Pandemi, Yeni Koronavirüs Hastalığı, uzaktan eğitim, öğretmen, çocuk, ebeveyn.

\section{Assessing of Parents' Distance Learning Experiences During Pandemic}

\begin{abstract}
The closure of schools in order to prevent the spread of the New Coronavirus Disease caused the distance education process to start for the first time in our country. This process, which is new for both teachers, students and parents, has provided different experiences. The study was conducted to evaluate the distance education experiences of parents during the pandemic process. The research was created with a qualitative research design and was carried out using the interview technique. There are 21 parents in the study group of the research. Research data were obtained by using a structured interview form. Descriptive analysis was used in the analysis of the research data. According to the results obtained, the majority of the parents participating in the research approve of the decision to close the schools, but they want the transition to formal education. It has been determined that parents spare time during the day for their children's education, have sufficient educational resources, and are satisfied with the support provided by the school. However, it has also been determined that they have technical, social, student-centered and education-centered difficulties in the distance education process and that teachers think that they can support by being understanding in the process. As a result, since distance education is a new situation for all parents, it is considered important that they are supported by teachers, even if the parents do not need it. Parents' need for teachers to inform and guide will motivate them to support their children in this process.
\end{abstract}

Keywords: Pandemic, New Coronavirus Disease, distance education, teacher, child, parent.

\section{Giriş}

Dünya çapında eğitimin her kademesinde öğrenim hayatına devam eden öğrencilerin neredeyse tamamı virüsün bulaşmasının azaltılabilmesi amacıyla Yeni Koronavirüs Hastalığı (COVID-19) sırasında okulların geçici olarak kapanması deneyimini yaşamıştır (Viner vd., 2020). Birleşmiş Milletler Eğitim, Bilim ve Kültür Örgütü'nün (UNESCO, 2020) COVID-19 salgını ile ilgili yayımladığı rapora göre dünya genelinde yaklaşık 200 ülkede okullar kapatılmış ve öğrencilerin \%90'ından fazlasının örgün eğitimlerinde kesinti yaşanmıştır. Okulların kapatılması, uzaktan eğitim, kontrollü ve sistematik açılma gibi uygulamalar ülkemizde de eğitim kapsamında alınan tedbirler arasında yerini almıştır. Yapılan araştırmalar salgınlar sırasında okulların kapatılmasının bulaşmanın 
azaltılması üzerinde etkili olduğunu ortaya koymuştur (Cowling vd., 2020; Nafisah, Alamery, Al Nafesa, Aleid ve Brazanji, 2018). Okulların kapatılması öğrencilerin, ebeveynlerinin ve öğretmenlerin günlük yaşamlarını daha önce görülmemiş bir şekilde değiştirmesine sebep olmuştur. Dünya genelinde yarım milyardan fazla çocuk evde kalıp uzaktan eğitime devam ederek sanal öğrenci olurken, ebeveynleri, kardeşleri ve diğer aile üyeleri çocukların eğitim hayatlarının olumsuz etkilenmemesi için birer eğitim koçuna dönüşmüş ve böyle destekleyici bir rol üstlenmişlerdir (Cohen ve Kupferschmidt, 2020). Pek çok öğretmen, aile ve öğrenci bu ani değişime hazırlıklı değildi ve çeşitli şekillerde çocuklarının eğitimlerine destek olmaya çalışırken artan ebeveyn katılımı da bazı zorlukların ve sorunların yaşanmasına sebep olmuştur.

Ebeveyn katılımı, geleneksel eğitim ortamlarında öğrencilerin başarısı için önemli bir faktördür. Pandemi nedeniyle uzaktan eğitime geçmeden önce çevrimiçi öğrenme ortamlarında ebeveynlerin desteği ile ilgili yapılan araştırmalar, ebeveyn desteğinin öğrenci başarısına önemli katkılar sağladığını ortaya koymuştur (Makrooni, 2019; Woofter, 2019). Liu, Black, Algina, Cavanaugh ve Dawson (2010) ebeveynlerin çocuklarının öğrenimi için yeni roller ve sorumluluklar üstlenmeleri gerektiğini vurgulamışlardır. Ancak, geleneksel eğitim sisteminde ebeveynler çocuklarına destek olabilmek için üstlenmeleri gereken görev ve sorumlulukların farkında iken, uzaktan eğitim sisteminde sahip olmaları beklenen rol ve sorumlulukları anlamakta güçlük çekebilmektedir (Murphy ve Rodriguez Manzanares, 2009). Yani uzaktan eğitim konusunda ebeveynlerin düşünceleri belirsiz olabilmektedir. Bazı ebeveynler çocuklarının okula ve ödevlerine karşı daha sorumlu olduklarını hissederken, bunu bir yük olarak gören ebeveynler de bulunmaktadır (Selwyn, Banaji, Hadjithoma Garstka ve Clark, 2011). Sorensen (2012) araştırmasında uzaktan eğitimin ebeveynler için zorlayıcı ve olumlu yönlerini ortaya çıkarmıştır. Araştırma sonucunda uzaktan eğitimin ebeveynler için en zorlayıcı durumu çocuklarını çevrimiçi programda tutabilme ve ders çalışmaları sağlama olarak tespit edilirken, en olumlu yönü çocukların çevrimiçi eğitim sırasında öğretmenleriyle etkileşime girmeleri olarak tespit edilmiştir. 2020 yılından beri devam eden uzaktan eğitim sistemi de göz önünde bulundurulduğunda, uzaktan eğitimin ebeveynlerin aktif katılımını destekleyebilmek için yeterli olanaklara sahip olmadığı görülmektedir. Goodall (2016) bu durumu teknolojinin etkin kullanımı ile sağlanabilen uzaktan eğitim sürecine öğrenciler ve öğretmenlerin yanı sıra ailelerin dahil edilmesi için yeterli alt yapıya sahip olunmadığı şeklinde ifade etmiştir. Ebeveynlerin uzaktan eğitime katılımını etkileyebilecek çeşitli faktörler bulunmaktadır. Ekonomik kaynaklar, internet erişiminin olmaması, teknolojinin kullanımına karşı ilgi duymama ve düşük dijital öz yeterliliğe sahip olma bu faktörler arasında değerlendirilmektedir (Beckman, Bennett ve Lockyer, 2019; Hollingworth, Mansaray, Allen ve Rose, 2011; Povey vd., 2016). Öğretmenlerin bakış açısına göre ebeveynlerin uzaktan eğitim sistemine aktif katılımı ile ilgili yapılan araştırma sonucunda öğretmenler ebeveynlerin öğrencilerin ders programlarını düzenlemek, öğrencilerin sınıf arkadaşlarıyla ilişkilerini desteklemek, öğretmen ve öğrenci arasındaki etkileşimi pekiştirmek, öğrencinin çevrimiçi derse katılımını takip etmek, öğrencinin çevrimiçi derse katılması için motive etmek ve öğrencileri yönlendirmek gibi durumlarda faydaları olduğu belirlenmiştir (Borup, 2016).

Uzaktan eğitim sürecinde ebeveynlerin aktif katılımı ve çocuklarına destek olmasının faydaları bahsedildiği gibidir, ancak pandemi sürecinde ebeveynlerin çocuklarının uzaktan eğitim sisteminden olabildiğince faydalanabilmelerini sağlayabilmelerinin önündeki en büyük engel uzaktan çalışma sistemi olarak karşımıza çıkmaktadır. Uzaktan çalışan ebeveynler, evden çalıştıkları için gün içinde eğitim çalışmalarında çocuklarına yeteri kadar yardımcı olamamaktadır (Reimers ve Schleicher, 2020). Uzaktan çalışma hem iş sorumluluklarının hem de evle ilgili sorumluluklarının aynı ortamda, aynı anda karşılanması durumunu ortaya çıkardığı için ebeveynlerin sorumluluklarında artışa sebep olmuştur. Evde birden fazla çocuğun bulunması durumunda uzaktan eğitime devam etme çocuklar için ayrıca önemli bir sorun olabilmektedir. Çünkü birden fazla bilgisayar, tablet ya da akılll cep telefonu gerekliliğinin yanı sıra çocukların teknik ve eğitimsel desteğe ihtiyaç duyması da ebeveynlerin işini zorlaştırmaktadır. Tüm bu faktörlerin yanı sıra ebeveynlerin dijital becerileri eksik olabilir, bu nedenle çocuklarına uzaktan eğitim çalışmalarında yardımcı olamayabilirler (Reimers ve Schleicher, 2020; Trust ve Whalen, 2020). Dijital beceri gerektiren teknik sorunların bulunmadığı hallerde ayrica aile üyelerinde hastalanma ve iş kaybı gibi farklı yaşamsal durumların olması da çocukların eğitime odaklanabilmelerini etkileyebilmektedir (Daniel, 2020). Anaokulu ve ilköğretim çağında bulunan 
çocukların dikkat süreleri kısadır ve eğitim sırasında uygulamalı öğrenme metotlarının kullanımı tercih edilmektedir. Bu nedenle küçük çocukların teknoloji yoluyla uzaktan eğitilmesi de zor olabilmektedir (Szente, 2020). Belirtilen pek çok zorluğa rağmen uzaktan eğitime geçilmiş olmasının en büyük faydası öğretmenler ve öğrenciler arasındaki ilişkinin ve etkileşimin sürdürülmüş olmasıdır. Öğrenciler, öğretmenlerini ve sınıf arkadaşlarını zaten tanıdıkları ve eğitim yıllarının çoğunu onlarla geçirdikleri için, öğretmenlerin uzaktan eğitime devam etmesi, öğrenciler ve ebeveynlerle var olan ilişkilerini sürdürebilmelerini kolaylaştırmıştır. Öğretmenlerin uzaktan eğitim sürecinde en büyük destekçileri de ebeveynler olmuştur (Daniel, 2020; Szente, 2020).

Pandemi sürecinde eğitim kapsamında yapılan pek çok araştırma olmuştur. Bu araştırmalarda uzaktan eğitim sisteminin değerlendiirlmesi, öğretmenlerin bakış açısıyla sürecin değerlendirilmesi, ebeveynlerin tutum ve düşüncelerinin değerlendirilmesi, farklı kademelerde bulunan öğrenciler üzerine olan etkilerinin değerlendirilmesi, idarecilerin süreci değerlendirmesi gibi farklı amaçlara yer verilmiştir (Bayburtlu, 2020; Sarı ve Nayır, 2020; Tümkan ve Tümkan, 2020). Pandemi nedeniyle eğitimin uzaktan devam etmesine karşın ebeveynlerin evde olumlu eğitim ortamının oluşturulmasına önemli katkıları olacağı düşünülmektedir. Ebeveynlerin bu olumlu ortamı oluşturmalarında öğretmenlerin rolü etkili olacaktır. Şahin ve Atbaşı (2020) çalışmalarında eğitim ortamlarının etkili olması için öğretmenlerin rolünü vurgulamışlardır. Eğitimin hangi kademesinde olursa olsun velilerin öğretmenlerin desteğine yönelik istekleri bulunmaktadır (Konca, 2020). Farklı değişkenlerin bulunmasıyla birlikte öğrencilerin ve ebeveynlerin pandemi sürecindeki deneyimlerinin bilinmesi, sunulacak uzaktan eğitim hizmetlerinin düzenlenmesi, ebeveynlere ve öğrencilere destek projelerinin hazırlanması adına önem taşımaktadır. Özellikle uzaktan eğitim sürecinde ebeveynlerin rollerinin incelenmesi hem ebeveynlerin farkındalıklarının artmasına hem de sunulan eğitim hizmetlerinin niteliğinin artırılması noktasında katkı sağlayıcı olacaktır. Bu doğrultuda yapılan çalışmada, pandemi sürecinde ebeveynlerin uzaktan eğitim deneyimlerinin değerlendirilmesi amaçlanmıştır. Temel araştırma sorusu; "ebeveynler uzaktan eğitim süreci deneyimlerini nasıl değerlendirmektedir?" şeklinde oluşturulmuştur.

\section{Yöntem}

Yöntem bölümünde araştırma için kullanılan araştırma modeli ve çalışma grubuna ilişkin bilgiler yer almaktadır. Yapılandırılmış görüşme formu ile ilgili bilgiler veri toplama araçları kısmında ifade edilmiştir. Yapılan görüşmeler ve görüşmelerin analizine de verilerin toplanması ve analizi başlığında değinilmiş̧tir.

\section{Araştırma Modeli}

$\mathrm{Bu}$ çalışma nitel araştırma deseniyle oluşturulmuştur. Araştırma, nitel araştırma yöntemlerinden durum çalışmasıdır (Yıldırım ve Şimşek, 2018). Uzaktan eğitim sürecinin ebeveynlerin kendi deneyimleri kapsamında, bütüncül olarak analiz edilebilmesi firsatı sağladığı için nitel araştırma desenlerinden durum çalışması tercih edilmiştir (Yıldırım ve Şimşek, 2018).

\section{Çalışma Grubu}

Araştırmaya 21 ebeveyn katılmıştır. Okulların kapalı olması ve uzaktan eğitimin devam etmesi nedeniyle araştırmaya katılacak ebeveynlerin belirlenebilmesi için çeşitli sınırlılıklar belirlenmiştir. $\mathrm{Bu}$ sınırlılıklar; Ankara İli Çankaya İlçesinde ikamet ediyor olma, pandemi sürecinde en az bir çocuğunun uzaktan eğitime devam ediyor olması, en az bir çocuğunun ilköğretim düzeyinde eğitime devam ediyor olması ve gönüllü olma olarak belirlenmiştir.

Çalışma nitel araştırma deseniyle oluşturulduğu ve ebeveynler ile görüşme yapılacağı için çalışma grubunun belirlenebilmesi için olasılıklı olmayan amaçlı örneklem seçimi yönteminden yararlanılmıştır. Çünkü bu yöntem görüşme yapılacak ebeveynlerin belirlenmesinde araştırma konusu ile doğrudan ilgili olup olmadıklarının değerlendirilmesi olanağı sunmaktadır (Yıldırım ve Şimşek, 2018). 
Ankara İli Çankaya İlçesinde bulunan özel bir ilköğretim okulunda araştırmanın amacı ve uygulama şekli hakkında duyuru yapılmıştır. Belirlenen tarih ve saatte araştırma hakkında ayrıntılı bilgi verilebilmesi için çevrimiçi bir toplantı düzenlenmiştir. Bilgilendirme toplantısı sonucunda araştırmaya katılmaya gönüllü olan ebeveynler belirlenmiştir. Çalışma grubunda bulunan ebeveynlere ilişkin bilgiler Tablo 1'de sunulmuştur.

Tablo 1

Çalıșma Grubunun Genel Özellikleri

\begin{tabular}{lcc}
\multicolumn{1}{c}{ Çalışma grubu } & Anne & Baba \\
\hline Cinsiyet & 17 & 4 \\
Eğitim düzeyi & 14 & 4 \\
Üniversite & 3 & \\
Lise & 1 & \\
Meslek & 2 & \\
Sinı öğretmeni & 1 & \\
Anaokulu öğretmeni & 4 & \\
Resim öğretmeni & 9 & 2 \\
Öğretim üyesi/görevlisi & & 1 \\
Eğitim dışı meslekler & 6 & 1 \\
Çocuk sayisı & 11 & 3 \\
1 & & 1 \\
2 & 13 & 4 \\
4 & 4 & \\
Okula devam eden çocuk sayısı & & \\
1 & 16 & \\
İnternet erişim durumu & & \\
Var & & \\
\hline
\end{tabular}

Görüşmeye katılmak için gönüllü olan 21 ebeveynden 17'si anne, 4'ü de babadır. $\mathrm{Bu}$ ebeveynlerin her biri farklı ailelere sahiptir, yani eş olan anne/baba katılımcısı bulunmamaktadır. Annelerin 14'ü üniversite mezunu, 3'ü de lise mezunu iken babaların tamamı üniversite mezunudur. Annelerden 8'inin mesleği eğitim ile ilgilidir. 1 sinıf öğretmeni, 2 anaokulu öğretmeni, 1 resim öğretmeni ve 4 tane de eğitim fakültesi öğretim üyesi/görevlisidir. Babaların hiçbirinin mesleği eğitim ile ilgili değildir. Annelerin 6'sının tek çocuğu, 11'inin de 2 çocuğu bulunmaktadır. Babaların 2'sinin tek çocuğu, 1'inin 2 çocuğu ve 1'inin de 4 çocuğu bulunmaktadır. Annelerden 13'ünün 1 çocuğu, 4'ünün de 2 çocuğu pandemi sürecinde okula devam etmektedir. Babalardan 3'ünün 1 çocuğu, 1'inin de 4 çocuğu pandemi sürecinde okula devam etmektedir. Annelerin 16'sının babaların da tamamının pandemi nedeniyle okullarının kapalı olduğu dönemlerde internete erişimleri vardır.

\section{Veri Toplama Araçları}

Araştırmada görüşme tekniği kullanılmıştır ve araştırma verileri yapılandırılmış görüşme formu kullanılarak elde edilmiştir. Bu teknikte, görüşülen ebeveynlerin verdikleri bilgiler arasındaki paralellik belirlenmeye çalışılmaktadır (Yıldırım ve Şimşek, 2018). Yapılandırılmış görüşme formunda pandemi sürecinde ebeveynlerin uzaktan eğitim deneyimlerini ortaya çıkarabileceği düşünülen önceden hazırlanmış sorulara yer verilmiştir. Demografik bilgiler dışında 7 tane soru hazırlanmıştır.

Açık uçlu olarak hazırlanan görüşme sorularında standart 7 soru bulunmaktadır ve ebeveynlerin bu soruları istedikleri şekilde cevaplamaları sağlanmıştır. Demografik bilgiler kısmından elde edilen bulgular çalışma grubu başlığı altında açıklanmıştır. Yapılan bilgilendirme toplantısında ebeveynlere yöneltilecek sorular hakkında açıklama yapılmıştır. Araştırmaya katılmadan önce ebeveynlerin sözlü bilgilendirilmiş onayı alınmıştır. 


\section{Verilerin Toplanması Süreci}

Görüşmeler 2021 yılının mart ayında yapılmıştır. Pandemi sürecinin devam etmesi ve okulların kapalı olması nedeniyle, sağlık önceliği dikkate alınarak araştırmacı tarafından gerçekleştirilen görüşmeler çevrimiçi olarak düzenlenmiştir. Her bir görüşme yaklaşı 30-40 dakika arasında sürmüştür. Araştırmacı tarafından hazırlanmış, yapılandırılmış görüşme sorularına ebeveynlerin verdikleri cevaplar kaydedilmiştir. Görüntülü yapılan görüşmeler ebeveynlerin izniyle kaydedilmiştir. 12 ebeveyn görüntülü kayıt yapılmasını istemediği için sadece ses kaydı yapılmıştır.

\section{Verilerin Analizi}

Araştırma verilerinin analizi, araştırma alt problem soruları kapsamında açıklanmıştır. Araştırmanın alt soruları:

1. Ebeveynlerin okulların kapatılması kararı hakkındaki düşünceleri nelerdir?

2. Ebeveynler uzaktan eğitim kapsamında çocuklarını nasıl desteklemektedir?

3. Ebeveynlerin uzaktan eğitim kapsamında yaşadıkları zorluklar nelerdir?

4. Ebeveynlerin yaşadıkları zorlukların giderilebilmesi kapsamında çözüm önerileri nelerdir?

5. Ebeveynlerin uzaktan eğitim kapsamında öğretmenlerden beklentileri nelerdir?

İkinci soruda ebeveynlerin çocuklarını desteklemeleri, birlikte çalışma süreleri, eğitim kaynakları, okulun desteğinin değerlendirilmesi gibi durumları kapsamaktadır. Yapılan araştırmanın verileri betimsel analizi yöntemi kullanılarak analiz edilmiştir. Betimsel yapılan analizde görüşme soruları dikkate alınarak veriler analiz edilmiştir. Böylelikle ebeveynlerin görüşme sorularına verdikleri cevaplar düzenlenmiş ve yorumlanmış şekilde açıklanmıştır.

Araştırma verilerinin analizinde görüşme soruları kullanılarak çerçeve oluşturulmuştur. Verilen cevaplar bu çerçeveye göre düzenlenmiştir. Bulguların tanımlanması, ebeveynlerin cevaplarından alıntılar yapılarak desteklenmiştir. Betimsel analiz sonucunda elde edilen veriler yorumlanmıştır.

Araştırmanın güvenirliğini sağlamak için elde edilen veriler üzerinden kodlayıcılar arası güvenirlik çalışması yapılmıştır. Nitel araştırma deneyimi bulunan bir başka araştırmacı tarafindan görüşme ses ve görüntü kayıtlarının \%20'si analiz edilmiştir. Analiz sonucu Miles ve Huberman (1994) tarafindan geliştirilen formül ile belirlenmiştir. Elde edilen sonuç \%80'nin üzerinde olduğu için araştırma güvenilir kabul edilmiştir.

\section{Araştırma Etiği}

Araştırma etik kurallara uygun şekilde gerçekleştirilmiştir. Araştırma için öncelikle Sağlık Bilimleri Üniversitesi Hamidiye Bilimsel Araştırmalar Etik Kurulu'ndan 21/225 sayılı karar numaras1 ile Etik Kurul Onayı alınmıştır.

\section{Bulgular}

Ebeveynlerden demografik bilgiler alındıktan sonra araştırma sorularına geçilmiştir. Ebeveynlerin pandemi sürecinde uzaktan eğitim deneyimlerini belirleyebilmek amaciyla hazırlanan sorulara verdikleri yanıtların tablo ile ifade edilmiştir. Tablo 2 ebeveynlerin okulların kapatılması kararı hakkındaki düşüncelerini göstermektedir.

Tablo 2

COVID-19 Salgını Sırasında Okulların Kapatılması Hakkındaki Düşünceler

\begin{tabular}{lcc}
\multicolumn{1}{c}{ Düsünceler } & Anne & Baba \\
\hline Kesinlikle kat1liyorum & 7 & 1 \\
Kat1liyorum & 4 & 3
\end{tabular}


Yapılan değerlendirme araştırmaya katılan ebeveynlerin çoğunluğunun (on beş ebeveyn) okulların kapatılması kararını onayladıklarını göstermektedir. Üç ebeveynin kapatılma kararı hakkında fikri olmadığını ifade ederken, üç ebeveyn de okulların kapatılması kararını uygun bulmadıklarını ifade etmişlerdir. Kararsızlık yaşayan ve kararı desteklemeyen ebeveynler annelerden oluşmaktadır. Araştırmaya katılan babaların tamamı kapatılma kararını desteklemektedir. Aşağıda ebeveynlerin verdikleri yanıtlardan bazı örnek ifadelere yer verilmiştir:

E5: "Ben doğru bir karar olduğunu düşünüyorum. Zaten yaygın hastalık varken çocuklarımızı korumamı gerekir öyle değil mi? Annenin görevi çocuğunu korumaktır. Ben okula açılsa da göndermeyebilirim bir süre emin olana kadar. Iç̧im rahat etmeli."

E20: "Haklı ve doğru bence. Yani biz yetişkin olarak kendimizi koruyamıyoruz. Çocuklar dikkatli olabilir ama ya dikkat etmez de hasta olursa. O yüzden doğru bence."

Tablo 3 ebeveynlerin okullar kapalıyken uzaktan eğitim kapsamında çocuklarını ne kadar süre desteklediklerini göstermektedir.

Tablo 3

COVID-19 Salgını Sirasında Okullar Kapalıyken Ebeveynlerin Çocuklarını Destekleme Süreleri

\begin{tabular}{lcc}
\multicolumn{1}{c}{ Süre (günde) } & Anne & Baba \\
\hline 1 saatten az & 4 & 2 \\
$1-2$ saat aras1 & 6 & 2 \\
3-4 saat aras1 & 2 & \\
5 saatten fazla & 5 & \\
\hline
\end{tabular}

Yapılan değerlendirme araştırmaya katılan sekiz ebeveynin gün içinde ortalama 1-2 saat arasında çocuklarını desteklediklerini göstermektedir. Altı ebeveyn günde 1 saatten az destek verdiğini ifade ederken, beş ebeveyn 5 saatten fazla desteklediğini ve iki ebeveyn de 3-4 saat arasında çocuğunu desteklediğini ifade etmiştir. Anneler açısından sonuç değerlendirildiğinde, çoğunluğu 1-2 saat arasında çocuğunu uzaktan eğitim için desteklerken çok yakın bir sonuçla beş tanesi de 5 saatten fazla desteklediğini ifade etmiştir. Babalar açısından değerlendirildiğinde eşit oranla 1 saatten az ve 1-2 saat arası destek verdikleri belirlenmiştir. Aşağıda ebeveynlerin verdikleri yanıtlardan bazı örnek ifadelere yer verilmiştir:

E2: "Eğitimi hakkında endişe duydum. Bu yüzden sürekli ders çalıştık. Sabah 10'da başladık, akşam 4'e kadar devam ettik."

E5: "Onunla daha fazla zaman ders çalışmaya çalıştım ama o bunu istemedi. Onu daha bir kendi halinde bırakmaya ona çok müdahale etmemeye gayret ettim."

E8: "Çocuklarımı rahatlatacak ve anlayacakları seviyede bilgilendirme yaptım ve ilgilendim. 3 saat ders çalıştık."

E10: "Özel ders aldırmaya başladım, günde 2 saat."

Tablo 4 pandemi döneminde ebeveynlerin uzaktan eğitim süresince sahip oldukları eğitim kaynaklarını değerlendirmelerini içermektedir.

Tablo 4

COVID-19 Salgını Sırasında Ebeveynlerin Erişebildikleri Eğitim Kaynakları

\begin{tabular}{lcc}
\hline \multicolumn{1}{c}{ Erişilebilir kaynaklar } & Anne & Baba \\
\hline Çok fazla kaynağım var & 5 & 3 \\
Yeterli miktarda kaynağa sahibim & 10 & 1
\end{tabular}


Çok az kaynağım var

1

Yeterli miktarda kaynağım yok

Yapılan değerlendirmede araştırmaya katılan ebeveynlerin çoğunluğunun (on bir ebeveyn) yeterli miktarda eğitim kaynağına sahip olduğunu göstermektedir. Sekiz ebeveyn çok fazla kaynağa sahip olduklarını ifade ederken bir ebeveyn az kaynağı olduğunu ve yine bir ebeveyn de yeterli miktarda eğitim kaynağına sahip olmadığını ifade etmiştir. Az kaynağı olan ve yeterli miktarda kaynağa sahip olmayan ebeveynler annelerden oluşmaktadır. Araştırmaya katılan babaların tamamı fazla kaynağa sahip olduklarını veya yeterli miktarda eğitim kaynağına sahip olduklarını ifade etmişlerdir. Aşağıda ebeveynlerin verdikleri yanıtlardan bazı örnek ifadelere yer verilmiştir:

\section{E1: "Derslere karşı ilgisi azaldı. O yüzden farklı kaynaklar edindim. İlgisini artırdık."}

E5: "Ben yeterli kaynağımız olduğunu düşünüyorum. Eksik olan şeyleri de zaten Eba'dan ediniyorum."

\section{E7: “Kaynak sorunu yaşamadık.”}

E18: "Biraz farklı kaynaklarımız olsun, çeşitleri olsun isterdim ama yoktu."

Pandemi yaşanması ve bu nedenle okulların kapatılması beklenmedik bir durum olduğundan ebeveynlerin okullardan sunulan desteğe ihtiyacı olabileceği düşünülmüştür. Bu nedenle ebeveynlere pandemi sürecinde okulların sağladığı destekten memnun olup olmadıkları sorulmuş ve konu hakkındaki düşünceleri Tablo 5'te sunulmuştur.

Tablo 5

COVID-19 Salgını Strasında Ebeveynlerin Okulların Sağladı̆̆ı Destek Hakkındaki Düşünceleri

\begin{tabular}{lcc}
\multicolumn{1}{c}{ Düşünceler } & Anne & Baba \\
\hline Çok Memnunum & 4 & \\
Memnunum & 10 & 2 \\
Kararsızım & 2 & 2 \\
Memnun değilim & 1 & 2 \\
\hline
\end{tabular}

Yapılan değerlendirme araştırmaya katılan ebeveynlerin çoğunluğunun (on altı ebeveyn) kapanma sürecinde okulun sağladığı destek konusunda memnun veya çok memnun olduklarını göstermektedir. İki ebeveyn okulun sağladığı destek konusunda kararsız olduğunu ifade ederken, üç ebeveyn de sunulan destek hizmetinden memnun olmadığını ifade etmiştir. Kararsızlık yaşayan ebeveynler annelerden oluşmaktadır. Babaların yarısı sunulan destek hizmetlerinden memnun olduğunu ifade ederken, diğer yarısı da memnun olmadığını ifade etmiştir. Aşağıda ebeveynlerin verdikleri yanıtlardan bazı örnek ifadelere yer verilmiştir:

\section{E1: "Ben memnunum.”}

E4: "Okulun bize çok desteği oldu, hep ulaştık."

E9: "Biraz daha iyi destek sağlanabilirdi diye düşünüyorum."

E:17: "Memnun olduğunu söyleyemem. Okulda yetkili birileri yok, derslerde sorunlar ve gecikmeler var, çocuklar uyum să̆layamıyor. Derse devam etmek istemiyor ama öğretmen bir şey yapmiyor."

Uzaktan eğitim sürecinde ebeveynler farklı nedenlerle çeșitli güçlükler yaşayabilmektedir. $\mathrm{Bu}$ güçlüklerin neler olduğunun belirlenebilmesi için ebeveynlere yaşadıkları güçlüklerin neler olduğu sorulmuş ve konu hakkındaki düşünceleri Tablo 6' da sunulmuştur. 
Tablo 6

COVID-19 Salgını Sirasında Ebeveynlerin Uzaktan Eğitim Kapsamında Yaşadıkları Zorluklar

\begin{tabular}{|c|c|c|}
\hline Zorluklar & Anne & Baba \\
\hline \multicolumn{3}{|l|}{ Teknik zorluklar } \\
\hline İnternet bağlantı sorunları & 2 & \\
\hline Mikrofon, kulaklık sorunları & 1 & \\
\hline EBA bağlanma sorunları & 2 & \\
\hline \multicolumn{3}{|l|}{ Sosyal zorluklar } \\
\hline Çocukların sıkılması & 5 & 1 \\
\hline Arkadaşları özleme & 4 & 1 \\
\hline Aile dostlarıyla görüşmeyi özleme & 2 & 1 \\
\hline \multicolumn{3}{|l|}{ Öğrenci merkezli zorluklar } \\
\hline Motivasyon eksikliği & 5 & 1 \\
\hline Dikkatinin çabuk dağılması & 2 & \\
\hline Çabuk sıkılma & 6 & 1 \\
\hline Uzaktan eğitime uyum sağlayamama & 3 & \\
\hline Derse katılmak istememe & 1 & 1 \\
\hline Çevrimiçi dersleri dinlemek istememe & 2 & 1 \\
\hline Bilgisayar başında durmakta zorlanma & 6 & 1 \\
\hline \multicolumn{3}{|l|}{ Eğitim merkezli zorluklar } \\
\hline Uygulama gerektiren derslerin yetersiz kalması & 1 & \\
\hline Sosyal motivasyon eksikliği & 4 & 1 \\
\hline Öğretmenlerin ilgisizliği & 1 & 1 \\
\hline Ders sürelerinin kısa olması & 1 & \\
\hline Konu anlatımı yetersizliği & 1 & \\
\hline Soru çözümü yetersizliği & 1 & \\
\hline Ders ișlemek yerine ödev verilmesi & 1 & \\
\hline
\end{tabular}

Yapılan değerlendirmede araştırmaya katılan ebeveynlerin verdikleri cevaplardan 4 ana tema belirlenmiştir. Bu temalar teknik zorluklar, sosyal zorluklar, öğrenci merkezli zorluklar ve eğitim merkezli zorluklar olarak belirlenmiştir. Babaların hiçbiri soruya verdikleri cevaplarda teknik zorluklar kapsamında değerlendirilebilecek herhangi bir açıklama yapmamıştır. Annelerin ikisi internet bağlantı sorunu ve Eğitim Bilişim Ağı (EBA) bağlanma sorunu yaşadıklarını ifade ederken biri de mikrofon ve/veya kulaklık kaynaklı sorunlar yaşadığını ifade etmiştir. Eğitim Bilişim Ağı'nın kısatlması olarak kullanılan EBA, Millî Eğitim Bakanlığı tarafından kurulmuş olup eğitsel içerik ağını ifade etmektedir ve uzaktan eğitim kapsamında bakanlık tarafından ülke genelinde kullanılmaktadır. Sosyal zorluklar açısından değerlendirildiğinde ebeveynlerin çoğunluğu (altı ebeveyn) çocukların sıkıldığını ifade ederken, beşi arkadaşlarını özledikleri için zorluk yaşadıklarını ve üçü de çocukların aile dostlarıyla görüşmeyi özledikleri için zorluk yaşadıklarını ifade etmiştir. Öğrenci merkezli zorluklar açısından değerlendirildiğinde ebeveynlerin çoğunluğu (yedi ebeveyn) çocuklarının çabuk sıkılma ve bilgisayar başında durmakta zorluk yaşama, altısı çocuklarının motivasyon eksikliği yaşama, üçü çocuklarının uzaktan eğitime uyum sağlayamama, üçü çocuklarının çevrimiçi dersleri dinlemek istememe, ikisi çocuklarının dikkatinin çabuk dağılması ve ikisi de çocuklarının derse katılmak istememeleri nedeniyle zorluk yaşadıklarını ifade etmiştir. Eğitim merkezli zorluklar açıssından değerlendirildiğinde ebeveynlerin çoğunluğu (beş ebeveyn) sosyal motivasyon eksikliği, ikisi öğretmenlerin ilgisizliği, biri uygulama gerektiren derslerin yetersiz kalması, biri ders sürelerinin kısa olması, biri öğretmenlerin konu anlatımı yetersizliği, biri soru çözümü yetersizliği ve biri de öğretmenlerin ders işlemek yerine ödev vermeleri nedeniyle eğitim merkezli zorluk yaşadıklarını ifade etmiştir.

\section{E1: "Yaşadığımız en büyük zorluk internet gidip gelmesi."}

E2: "Mikrofon, kulaklık arızası çok yaşadık bu yüzden öğretmeni anlamakta zorluk çektik zoomdan ebadan düşüler geri bağlanmak uzun sürdü."

E5: "Çocuklar evde zaman geçirmekten çok sıkıldılar, arkadaşlarını çok özlediler, misafirlikte dostlarımıza gitmeyi özlediler." 
E7: "Ders dinlerken çocuğun ilgisi sürekli dă̆gllyor derse katılımı zor oluyor."

E11: "Çocuğumu uzun saatler boyunca bilgisayar başında tutmak zor oluyor. Bununla birlikte uygulama gerektiren derslerden çocuğumun yeteri kadar verim alamadığını düşünüyorum."

E20: "Uzaktan eğitimde süre azdı. Konu anlatımı ve soru çözümü yetersizdi. Tam olarak anlaşılamayan konulardan bol bol ödev verilmeliydi. Bu arada internet slkıntıları fazla yüklenmeden dolayl..."

\section{E21: "En büyük zorluk derse giremediğimiz zamanlard.."}

Yaşadıkları zorlukları ifade eden ebeveynlere daha sonra bu zorlukların giderilebilmesi için önerilerinin neler olduğu sorulmuş ve konu hakkındaki düşünceleri Tablo 7'de sunulmuştur.

Tablo 7

COVID-19 Salgını Sirasında Ebeveynlerin Eğitim Kapsamında Yaşadıkları Zorlukların Giderilebilmesi İçin Çözüm Önerileri

\begin{tabular}{lcc}
\hline \multicolumn{1}{c}{ Öneriler } & Anne & Baba \\
\hline Eğitim merkezli öneriler & & \\
Düzenli eğitim ortamı ve programının hazırlanması ve uygulanması & 3 & 4 \\
Öğretmenlerin mikrofon, kulaklık sorunlarının giderilmesi & 3 & 4 \\
Örgün eğitime geçilmesi & 7 & 4 \\
Uygulamalı derslerin yüz yüze verilmesi & 2 & \\
Aile eğitimlerinin düzenlenmesi & 2 & \\
Aile rehberlik hizmetlerinin verilmesi & 2 & 3 \\
Yüz yüze eğitimdeki kriterlerin uzaktan eğitimde de uygulanması & 2 & 1 \\
Eğlendirici ve dikkat çekici eğitim ortamının oluşturulması & 1 & 1 \\
Evde eğitime yönelik materyallerin hazırlanması & & \\
\hline Sosyal durumlara ilişkin öneriler & 4 \\
Oyun ortamının oluşturulması & \\
\hline
\end{tabular}

Yapılan değerlendirmede araştırmaya katılan ebeveynlerin verdikleri cevaplardan 2 ana tema belirlenmiştir. Bunlar eğitim merkezli öneriler ve sosyal durumlara ilişkin öneriler olarak belirlenmiştir. Ebeveynlerin eğitim merkezli önerileri kapsamında 9 alt tema belirlenmiştir. Ebeveynlerin çoğunluğunun (on bir ebeveyn) önerisi örgün eğitime geçilmesi olarak belirlenmiştir. Yedi ebeveyn düzenli eğitim ortamı ve programının hazırlanması ve uygulanmasını, yedi ebeveyn öğretmenlerin mikrofon ve/veya kulaklık sorunlarının giderilmesini, altı ebeveyn yüz yüze eğitimdeki kriterlerin uzaktan eğitimde de uygulanmasını, üç ebeveyn eğlendirici ve dikkat çekici eğitim ortamının oluşturulmasını, iki ebeveyn uygulamalı derslerin yüz yüze verilmesini, iki ebeveyn aile eğitimlerinin düzenlenmesini, iki ebeveyn aile rehberlik hizmetlerinin verilmesini, iki ebeveyn de evde eğitime yönelik materyallerin hazırlanmasını önermiştir. Sosyal durumlara ilişkin öneriler açısından değerlendirildiğinde dört anne uzaktan eğitim sürecine oyun ortamının dahil edilmesini önermiştir. Babaların hiçbiri soruya verdikleri cevaplarda sosyal durumlara ilişkin öneriler kapsamında değerlendirilebilecek herhangi bir açıklamada bulunmamıştır. Aşağıda ebeveynlerin verdikleri yanıtlardan bazı örnek ifadelere yer verilmiştir:

E1: "Sorun bizden kaynaklı olunca bi şekilde hallettik ama ögretmen kulaklĭ̆ını mikrofonunu değiştirmediği için kuzım derse girmek istemedi."

E2: "Bence hiçbir şey. Evde eğitim bu yaş grubuna uygun değil."

E4: "Okullar öğrenci sayılarına göre haftanın belli günlerinde sınırlı sayıda öğrenciye uygulamalı dersleri yüz yüze verebilir." 
E8: "Yüz yüze ĕgitimdeki kriterler uzaktan ĕgitimde uygulanabilirdir. Bu durum başta ögretmenlerin sonrasında da öğrenci ve velilerin işine geldi. Hafifletmek için kurallar zorlayıcı olmallydl."

E13: "Tabiki yüz yüze eğitim olması. Ama gerçekten. Hafta aldı̆̆ matematik dersi az soru çözümü az. Özellikle soru çözümü yok gibiydi. Süreler kisitll. Öğretmenler okula gider gibi derse hazırlanmalı. Evde eğitime yönelik materyalleri olmall. Ödev vermekle iş bitmiyor."

E17: "Devlet tarafindan ögretmen, aile ve çocuğa psikolojik destek gerektiğini düşünüyorum. Sonra ütopyalardan distopyalara evriliyorum."

\section{E19: "Aile eğitimi verilebilir."}

Ebeveynlere yaşanan süreçte öğretmenlerin nasıl desteklemelerine ihtiyaç duydukları sorulmuş ve konu hakkındaki düşünceleri Tablo 8'de sunulmuştur.

Tablo 8

COVID-19 Salgını Strasında Ebeveynlerin Uzaktan Eğitim Sürecinde Öğretmenlerden Beklentileri

\begin{tabular}{lcc}
\multicolumn{1}{c}{ Beklentiler } & Anne & Baba \\
\hline Verilen desteğin yeterli olduğunu düşünüyorum & 4 & 2 \\
Öğretmenlerin dersleri düzenli işlemesi & 2 & 2 \\
Öğretmenlerin çocuklarla etkileşim kurması & 2 & 1 \\
Öğretmenlerin kaynaklara erişim konusunda bilgilendirmesi & 3 & 1 \\
Öğretmenlerin destekleyici ve ulaşıllabilir olması & 2 & 1 \\
Teknolojiyi kullanma konusunda beceri düzeylerinin yüksek olması & 1 & 1 \\
Öğrenci durumu ile ilgili bilgilendirme & 4 & \\
Günlük ödev verilmesi ve takip edilmesi & 4 & 1 \\
Çocukların motivasyonu konusunda ailelerin yönlendirilmesi & 3 & \\
Öğretmenlerin velilerle daha fazla iletişim kurması & 4 & 1 \\
Okulda yüz yüze eğitimin desteklenmesi & 3 & 1 \\
Bireysel öğrenci görüşmeleri ile motivasyon artırma çalışmaları & 5 & 2 \\
Mümkün olduğunca okul ortamının oluşturulabilmesi & 2 \\
Anlayışlı davranma & 5 & 2 \\
Ek ders yapılması & 4 \\
\hline
\end{tabular}

Yapılan değerlendirme araştırmaya katılan ebeveynlerin çoğunluğunun (yedi ebeveyn) öğretmenlerin süreçte anlayışlı davranarak destek olabileceklerini, altı ebeveyn öğretmenlerin bireysel öğrenci görüşmeleri yaparak motivasyon artırma çalışmaları kapsamında destek olabileceklerini, altı ebeveyn öğretmenlerden yeterli destek aldığını düşündügünü, beş ebeveyn öğretmenlerin öğrencilerin durumu ile ilgili bilgilendirme yaparak destek olabileceklerini, dört ebeveyn öğretmenlerin dersleri düzenli işleyerek destek olabileceklerini, dört ebeveyn öğretmenlerin günlük ödev vererek ve ödevleri takip ederek destek olabileceklerini, dört ebeveyn öğretmenlerin velilerle daha fazla iletişim kurarak destek olabileceklerini, dört ebeveyn öğretmenlerin okulda yüz yüze eğitimi destekleyerek destek olabileceklerini, dört ebeveyn öğretmenlerin ek ders yaparak destek olabileceklerini, dört ebeveyn öğretmenlerin çocukların motivasyonu konusunda aileleri yönlendirerek destek olabileceklerini, üç ebeveyn öğretmenlerin çocuklarla etkileşim kurarak destek olabileceklerini, üç ebeveyn öğretmenlerin kaynaklara erişim konusunda bilgilendirme yaparak destek olabileceklerini, üç ebeveyn öğretmenlerin destekleyici ve ulaşılabilir olarak destek olabileceklerini, iki ebeveyn öğretmenlerin çevrimiçi ders sırasında mümkün olduğunca okul ortamını oluşturarak destek olabileceklerini ve bir ebeveyn de öğretmenlerin teknolojiyi kullanma konusunda beceri düzeyi yüksek olarak destek olabileceklerini ifade etmiştir. Aşağıda ebeveynlerin verdikleri yanıtlardan bazı örnek ifadelere yer verilmiştir:

\section{E9: "Desteklediler şükür sağolsunlar."}

E11: "Kaynaklarla, canlı derslerle, görüntülü görüssmelerle, rehberlikleriyle neyi nasıl göstermeleri gerektiği ayrıntılı açıklamalarıyla" 
E14: "Öğrenci durumu ile ilgili sürekli bilgilendirme, günlük ödev verilmesi”

E16: "Çocuğu nasıl destekleyeceğimi motive edeceğimi anlatmalarını isterim."

E17: "Slk sık irtibatta kalarak sıkı ögrrenci takibi ile”

E19: "WhatssApp üzerinden haftada bir bireysel görüşmeler sağlayıp moral motivasyon olabilir diye düşünüyorum."

E20: "Uzaktan eğitim almaya devam etti oğlum. Öğretmeni de hem evde yapılabilecek etkinlikler konusunda hem de çocuğumun ruh sağlığl ve gelişimi üzerinde önemli katkıları oldu."

E21: "Karşıllıklı anlayış"

\section{Sonuç, Tartışma ve Öneriler}

Yapılan çalışmada, pandemi sürecinde ebeveynlerin uzaktan eğitim deneyimlerinin incelenmesi amaçlanmıştır. Araştırma kapsamında ebeveynlerin okulların kapatılması kararı hakkındaki düşünceleri değerlendirilmiştir. Yapılan değerlendirme araştırmaya katılan ebeveynlerin çoğunluğunun okulların kapatılması kararını onayladıklarını göstermektedir. Salgın hastalıkların toplu alanlarda bulaşma riskinin fazla olduğunun basın yoluyla ifade edilmesinin ebeveynlerin bu kararı onaylaması üzerinde etkili olduğu düşünülmektedir. Ayrıca, okulların kapatılması, 18 yaş altında bulunan çocuklara sokağa çıkma yasağı uygulanması, iş yerlerinin kapatılması ve uzaktan çalışma imkanlarının oluşturulması da etkili olabilecek diğer faktörler arasında ifade edilebilir. Yetişkinlerin hastalanma olasılıklarının fazla olmasına karşın ebeveynler çocuklarını korumak istemektedir. Çocuklarının sağlığını korumak ve onları güvende hissettirmek ebeveynlerin öncelikli görevleri arasında yer almaktadır. Erol ve Erol (2020) pandemi sürecinin ilköğretim öğrencileri üzerine etkilerini inceledikleri araştırmalarında hem ebeveynlerin hem de çocukların salgın nedeniyle korku ve kaygı durumları geliştirdiklerini tespit etmişlerdir. Çocuklar ebeveynlerini hastalık nedeniyle kaybetme korkusunu daha fazla yaşarken, ebeveynler çocuklarına okuldan hastalık bulaşması korkusu ve okulların yeteri kadar hijyenik olmaması kaygısı yaşadıklarını ortaya çıkarmışlardır. COVID-19 salgınının kolay bulaşabilen enfektif bir hastalık olmasından dolayı ebeveynlerin çocuklarının sağlığını düşünerek titiz davranmaları, koruyucu ve kollayıcı düşünerek okulların kapalı olması kararını doğru bulmaları beklenen bir sonuç olarak değerlendirilmektedir.

Ebeveynlerin okullar kapalıyken uzaktan eğitim kapsamında çocuklarını ne kadar süre destekledikleri değerlendirilen bir diğer husus olmuştur. Yapılan değerlendirme araştırmaya katılan ebeveynlerin çoğunluğunun (sekiz ebeveyn) gün içinde ortalama 1-2 saat arasında çocuklarını desteklediklerini göstermektedir. İlköğretime devam eden öğrencilerin yaşları genellikle 6-11 arasında değişim göstermektedir. Bu yaş grubu çocukların daha önce hiç deneyimlemedikleri uzaktan eğitim sistemine kısa bir sürede uyum sağlayabilmesi için ebeveynlerin çocuklarına destek vermeleri gerekmektedir. Bu destek hem teknik boyutta hem de motivasyon kazandırma boyutunda olmalidır. Ekonomik İşbirliği ve Kalkınma Örgütü (OCED, 2020) pandemi sürecinde eğitim hizmetlerini değerlendirdiği araştırma sonuç raporunda öğrencilerin eğitimlerinin sürdürülebilmesi, öğrenmenin sağlanabilmesi, eksiği bulunan öğrencilerin desteklenebilmesi konularında ebeveynlerin takip, destek ve okul ile iş birliğine ihtiyaçları olduğunu belirtmiştir.

Ebeveynlerin uzaktan eğitim süresince sahip oldukları eğitim kaynakları yönünde yapılan değerlendirme; araştırmaya katılan ebeveynlerin çoğunluğunun (on bir ebeveyn) yeterli miktarda eğitim kaynağına sahip olduğunu, sekiz ebeveynin de çok fazla kaynağa sahip olduklarını göstermektedir. Okulların kapanması nedeniyle çocukların eğitim hayatlarının olumsuz etkilenmesini önleyebilmek adına uzaktan eğitim için yeterli eğitim kaynaklarına sahip olmak oldukça önemlidir. Ebeveynlerin, çocuklarının evde öğrenirken kullanabilecekleri kaynaklara ihtiyacı vardır. Çünkü ebeveynlik sorumluluklarının yanı sıra artık eğitimsel sorumlulukları da bulunmaktadır. Bu nedenle ebeveynlerin kaynak sorunu yaşamamaları önemli bir sonuç olarak değerlendirilmektedir. Pandemi 
sürecinde uzaktan eğitim ve eğitim kaynakları hakkında yapılan diğer araştırma sonuçları ebeveynlerin EBA sisteminin eğitim açısından verimli olduğunu düşündüklerini ortaya koymuştur (İnci Kuzu, 2020; Yılmaz, 2020). Ayrıca uzaktan eğitim kapsamında hem televizyon hem de diğer dijital teknolojik araçların kullanımının farklı alternatifler oluşturması, bilgiye erişimi kolaylaştırması ve faydalı içeriklerin çocuklara sunulması açısından da ebeveynlerin süreçten memnun olduklarını ortaya koyan araştırmalar bulunmaktadır (Çiftçi, Taşkaya ve Alemdar, 2013; Özgümüş, 2018; Tüysüz ve Çümen, 2016).

Ebeveynlerin pandemi sürecinde okulların sağladığı destekten memnuniyet düzeyleri hususunda yapılan değerlendirme; araştırmaya katılan ebeveynlerin çoğunluğunun (on altı ebeveyn) kapanma sürecinde okulun sağladığı destekten memnun veya çok memnun olduklarını göstermektedir. Çocukların eğitim hayatlarının süreçten olumsuz etkilenmemesi için okul-ebeveyn-öğretmen iş birliğinin sağlamasının önemli olduğu düşünülmektedir. Çalışma yapılan grup öğrencilerin ilkokul düzeyinde bulunmaktadır. Çocukların yaşları göz önünde bulundurulduğunda odaklanma sorunu yaşamaları ve dersler için desteğe ihtiyaçlarının olması beklenen durumlar kapsamında değerlendirilebilir. Çalışma yapılan ebeveynlerin çoğunluğunun (on üç ebeveyn) mesleği eğitimle ilgili değildir. Genel anlamda değerlendirildiğinde ebeveynlerin eğitim ve eğitmenlik konusunda bilgi, beceri ve deneyim sahibi olması da beklenemez. Özellikle ebeveynlerin eğitim alanında yeterli bilgi ve deneyime sahip olmamaları ve okula devam eden çocukların ilk çocukları olduğu durumu göz önünde bulundurulduğunda okul tarafindan ebeveynlere gerekli desteğin sağlanmasının önemli olduğu düşünülmektedir. Çünkü Chang (2018) özellikle ilköğretim düzeyinde uzaktan eğitime devam eden öğrencilerin eğitimlerini çevresel destek almadan kendi kendilerini sürdürmek zorunda kalmaları durumunda çocuklarda yalnızlaşma, uyumsuzluk ve motivasyon eksikliği gibi olumsuz psikolojik durumlar yaşanabileceğini ileri sürmektedir. Ebeveynlerin de süreçte motivasyona gereksinimi bulunmaktadır. Çocukların sağlıkları kadar eğitim hayatların da onlar için oldukça önemlidir. $\mathrm{Bu}$ nedenle okul tarafından girişimlerinin desteklenmesinin, yalnız olmadıklarını fark edebilmelerinin ve yapabilecekleri hakkında bilinçlerindirilmelerinin çocuklarının eğitimlerine dolaylı olarak olumlu katk1 sağlayabileceği düşünülmektedir.

Ebeveynlerin uzaktan eğitim konusunda yaşadıkları zorlukların belirlenebilmesi amacıyla yapılan değerlendirmede araştırmaya katılan ebeveynlerin teknik zorluklar, sosyal zorluklar, öğrenci merkezli zorluklar ve eğitim merkezli zorluklar yaşadıkları belirlenmiştir. Diğer alanlara kıyasla öğrenci merkezli zorluk yaşadığını ifade eden ebeveynler daha fazla olmuştur. Çocuklar yaşları gereği de dikkatleri çabuk dağılabilmekte ve hareket halinde olmak istemektedir. Bu yaş grubu için sokağa çıkma yasağının da bulunması enerjilerini boşaltmaları konusunda sorun yaşamalarına sebep olabilmektedir. Bu nedenlerle, uzun süre ekran karşısında oturabilme çocuklar için oldukça zor bir durum olarak değerlendirilebilir. Hareket kısıtlaması yaşayan çocukların motivasyon eksikliği yaşamaları, dikkatlerinin çabuk dağılması, çabuk sıkılmaları, uzaktan eğitime uyum sağlayamamaları, derse katılmak istememeleri, çevrimiçi dersleri dinlemek istememeleri ve bilgisayar başında durmakta zorlanmaları beklenen sonuçlar arasında değerlendirilebilir. Çünkü bu yaş grubu çocukların akranlarıyla ve öğretmenleriyle sosyal etkileşimde bulunmaya gereksinimi vardır. Huebner, Suldo, Valois, Darne ve Zullig (2004) yaptıkları araştırma sonucuna göre ilköğretim düzeyinde bulunan öğrencilerin akranlarıyla etkileşim ve iletişiminin çok az olmasının akademik başarı ve ilgilerini olumsuz yönde etkilemektedir. Bu yaş grubu çocukların öğretmenleri ve arkadaşlarıyla daha çok birebir ilişki kurabildikleri bir eğitim ortamına ihtiyaçları bulunmaktadır.

Ebeveynlerin yaşadıkları bu zorlukların giderilebilmesi için önerilerinin neler olduğu kapsamında yapılan değerlendirmede araştırmaya katılan ebeveynlerin çoğunluğunun (on bir ebeveyn) önerisi örgün eğitime geçilmesi olarak belirlenmiştir. Diğer öneriler olarak düzenli eğitim ortamı ve programının hazırlanması ve uygulanması, öğretmenlerin mikrofon ve/veya kulaklık sorunlarının giderilmesi, yüz yüze eğitimdeki kriterlerin uzaktan eğitimde de uygulanması, eğlendirici ve dikkat çekici eğitim ortamının oluşturulması, uygulamalı derslerin yüz yüze verilmesi, aile eğitimlerinin düzenlenmesi, aile rehberlik hizmetlerinin verilmesi, evde eğitime yönelik materyallerin hazırlanması şeklinde tespit edilmiştir. Elde edilen bu bulgular değerlendirildiğinde ebeveynlere göre uzaktan eğitimin örgün eğitimin yerini alamadığı şeklinde yorumlanabilir. Özellikle ilköğretim çağında 
bulunan çocukların yüz yüze etkileşime gereksinimi bulunmaktadır. Çünkü ebeveynler eğitimciler kadar çocukları değerlendiremeyebilirler. Çocukların eksikliklerinin belirlenebilmesi ve uygun şekilde desteklenebilmeleri açısından profesyonel yönlendirmeye ihtiyaçları bulunmaktadır. Erol ve Erol (2020) da yaptıkları araştırma sonucunda benzer şekilde ebeveynlere göre uzaktan eğitim tam anlamıyla eğitim amaçlarını kapsamadığı ve uzaktan eğitimin yüz yüze eğitim kadar etkili olmadığı sonucuna ulaşmışlardır. Ebeveynlerin diğer öneriler arasında teknik sorunların giderilmesi durumu belirtilmiştir. Can (2020) araştırması sonucunda plansız şekilde hayatımıza giren uzaktan eğitim sisteminin altyapı, erişim, güvenlik, içerik, tasarım, uygulama, kalite, mevzuat ve pedagojik açıdan güçlendirilmesi gerektiğini vurgulamıştır.

Uzaktan eğitim sürecinde öğretmenlerin ebeveynleri nasıl desteklemelerini istedikleri yönünde yapılan değerlendirmede araştırmaya katılan ebeveynlerin çoğunluğu (yedi ebeveyn) öğretmenlerin süreçte anlayışlı davranarak destek olabileceklerini ifade etmiştir. Diğer öneriler arasında çoğunlukla öğretmenlerin bireysel öğrenci görüşmeleri yaparak motivasyon artırma çalışmaları kapsamında destek olabilecekleri ve öğretmenlerin öğrencilerin durumu ile ilgili bilgilendirme yaparak destek olabilecekleri şeklinde olmuştur. Verilen desteğin yeterli olduğunu ifade eden ebeveynler de bulunmaktadır. Okul tarafından verilen desteğin de yeterli bulunması ile bu sonuç birbirini desteklemektedir. Uzaktan eğitim tüm ebeveynler için yeni bir olgu olduğu için eğitim kapsamında yeterliliğe sahip olan öğretmenler tarafından, ebeveynler ihtiyaç duymasalar bile, desteklenmelerinin önemli olduğu düşünülmektedir. Ebeveynlerin öğretmenlerin bilgilendirmesine ve yol göstermesine olan ihtiyaçları bu süreçte çocuklarını destekleyebilmeleri için de motivasyon sağlayabilecektir. İnci Kuzu (2020) yaptığı araştırmada uzaktan eğitim sürecinde velilerin çoğunluğunun öğretmenlerden destek aldığını, iletişim halinde olduğunu ve bu durumun çocuklar üzerinde olumlu sonuçları olduğunu belirlemiştir. Öğretmenlerin hem öğrencileri hem de ebeveynleri ile düzenli iletişim halinde olması gerekmektedir. Ebeveynlerin bu süreci uygun şekilde yönetebilmeleri için de öğretmenler tarafından rehberlik yapılmasına gereksinimleri olduğu düşünülmektedir. Ebeveynlerin de önerilerinde belirtiği gibi anlayışlı olma, bireysel değerlendirme, motivasyon artırma çalışmaları planlama, daha fazla iletişim kurma, çocuklarla etkileşim kurma, kaynaklara erişim imkanları oluşturma süreç yönetimi ile doğrudan ilişkilidir. $\mathrm{Bu}$ nedenle ebeveynlere süreç yönetimi ile ilgili eğitimlerin verilmesi, rehberlik hizmetlerinin sağlanması ve öğretmenlerin ebeveynler ile düzenli iletişim kurması gerekmektedir.

\section{Yazarların Katkı Oranı}

Çalışma tek yazarlı olduğu için yazarın katkı oranı \%100'dür.

\section{Çıkar Çatışması}

Bu çalışmada çıkar çatışması oluşturacak bir husus yoktur.

\section{Kaynaklar}

Bayburtlu, Y.S. (2020). Covid-19 pandemi dönemi uzaktan eğitim sürecinde öğretmen görüşlerine göre Türkçe eğitimi. Turkish Studies, 15(4), 131-151. https://dx.doi.org/10.7827/TurkishStudies.44460

Beckman, K., Bennett, S. and Lockyer, L. (2019). Reproduction and transformation of students' technology practice: The tale of two distinctive secondary student cases. British Journal of Educational Technology, 50(6), 3315-3328. https://doi.org/10.1111/bjet.12736

Birleşmiş Milletler Eğitim, Bilim ve Kültür Örgütü. (2020). Reopening schools: When, where and how? Retrieved from https://en.unesco.org/news/reopening-schools-when-where-and-how in 18.03.2021 
Borup, J. (2016). Teacher perceptions of parental engagement at a cyber high school. Journal of Research in Technology in Education, 48(2), 67-83. https://doi.org/10.1080/15391523.2016.1146560

Can, E. (2020). Coronavirüs (COVID-19) pandemisi ve pedagojik yansımaları: Türkiye'de açık ve uzaktan eğitim uygulamaları. Açıöŏgretim Uygulamaları ve Araştırmaları Dergisi, 6(2), 1153.

Chang, J. (2018). Influencing factors and coping strategies of students' engagement in the context of internet education. 9th International Conference on Information Technology in Medicine and Education (ITME). Hangzhou, 517-520. doi: 10.1109/ITME.2018.00120.

Cohen, J. and Kupferschmidt, K. (2020). Countries test tactics in 'war' against COVID-19. Science, 367(6484), 1287-1288. https://doi.org/10.1126/science.367.6484.1287

Cowling, B. J., Ali, S. T., Ng, T. W., Tsang, T. K., Li, J. C., Fong, M. W., Liao, Q., Kwan, M. Y. W., Lee, S. L., Chiu, S. S., Wu, J. T., Wu, P. and Leung, G. M. (2020). Impact assessment of nonpharmaceutical interventions against COVID-19 and influenza in Hong Kong: An observational study. MedRxiv. Advance online publication. The Lancet Public Health, 5(5), 279-288. https://doi.org/10.1101/2020.03.12.20034660

Çiftçi, S., Taşkaya, S. M. ve Alemdar, M. (2013). Sınıf öğretmenlerinin fatih projesine ilişkin görüşleri. Illkögretim Online, 12(1), 227-240.

Daniel, J. (2020). Education and the COVID-19 pandemic. Propsects, 49(1), 91-96.

Ekonomik İşbirliği ve Kalkınma Örgütü. (2020). A framework to guide an education response to he Covid-19 Pandemic of 2020. Retrieved from https://oecd.dambroadcast.com/pm_7379_126_126988-t63lxosohs.pdf in 16.03.2021

Erol, M. ve Erol, A. (2020). Koronavirüs pandemisi sürecinde ebeveynleri gözünden ilkokul öğrencileri. Milli Ĕ̈itim Dergisi, 49(1), 529-551.

Goodall, J. (2016). Technology and school-home communication. International Journal of Pedagogies \& Learning, 11(2), 118-131. https://doi.org/10.1080/22040552.2016.1227252

Hollingworth, S., Mansaray, A., Allen, K. and Rose, A. (2011). Parents' perspectives on technology and children's learning in the home: Social class and the role of the habitus. Journal of Computer Assisted Learning, 27, 347-360. https://doi.org/10.1111/j.1365- 2729.2011.00431.x

Huebner, E. S., Suldo, S. M., Valois, R. R., Darne, J. W. and Zullig, K. (2004). Brief multidimensional students' life satisfaction scale: Sex, race, and grade effects for high school sample. Psychological Reports, 94(1), 351-356. https://doi.org/10.2466/PR0.94.1.351-356

İnci Kuzu, Ç. (2020). COVID-19 pandemisi sürecinde uygulanan ilkokul uzaktan eğitim programı (EBA TV) ile ilgili veli görüşleri. Milli Eğitim Dergisi, 49(1), 505-527.

Konca, A. S. (2020). Velilerin okul öncesi eğitim hakkında görüşlerinin incelenmesi. Ahi Evran Üniversitesi Sosyal Bilimler Enstitüsü Dergisi, 6(3), 892-902.

Liu, F., Black, E., Algina, J., Cavanaugh, C. and Dawson, K. (2010). The validation of one parental involvement measurement in virtual schooling. Journal of Interactive Online Learning, 9(2), $105-132$. 
Makrooni, G. (2019). Being a first-generation migrant family student in Finland: Perceptions and experiences of the educational journey to higher education. Journal of Ethnic and Cultural Studies, 6(3), 157-170. http://dx.doi.org/10.29333/ejecs/293

Miles, M. B. and Huberman, A. M. (1994). Qualitative data analysis: An expanded sourcebook. New York: Sage Publications, Inc.

Murphy, E. and Rodriguez-Manzanares, M. A. (2009). Teachers' perspectives on motivation in high school distance education. Journal of Distance Education, 23(3), 1-24.

Nafisah, S. B., Alamery, A. H., Al Nafesa, A., Aleid, B. and Brazanji, N. A. (2018). School closure during novel influenza: A systematic review. Journal of Infection and Public Health, 11(5), 657-661. https://doi.org/10.1016/j.jiph.2018.01.003

Özgümüş, Ö. (2018). Bursa ilinde öğrenci-veli-ögretmenlerin eğitim bilişsim ă̆ının kullanım sıklığının belirlenmesi. Yüksek Lisans Tezi, Uludağ Üniversitesi, Eğitim Bilimleri Enstitüsü, Bursa.

Povey, J., Campbell, A. K., Willis, L.-D., Haynes, M., Western, M., Bennett, S., Antrobus, E. and Pedde, C. (2016). Engaging parents in schools and building parent-school partnerships: The role of school and parent organization leadership. International Journal of Educational Research, 79(2016), 128-141. https://doi.org/10.1016/j. Ijer.2016.07.005

Reimers, F. M. and Schleicher A. (2020). A framework to guide an education response to the COVID19 pandemic of 2020. Retrieved from https://oecd.dam-broadcast.com/pm_7379_126_126988t631xosohs.pdf in 25.03.2021

Sarı, T. ve Nayır, F. (2020). Pandemi dönemi eğitim: Sorunlar ve firsatlar. Electronic Turkish Studies, 15(4), 959-975. https://dx.doi.org/10.7827/TurkishStudies.44335

Selwyn, N., Banaji, S., Hadjithoma-Garstka, C. and Clark, W. (2011). Providing a platform for parents? Exploring the nature of parental engagement with school learning platforms. Journal of Computer Assisted Learning, 27(4), 314-323. https://doi.org/10.1111/j.13652729.2011.00428.x

Sorensen, C. (2012). Learning online at the K-12 level: A parent/guardian perspective. International Journal of Instructional Media, 39(4), 297-307.

Szente, J. (2020). Live virtual sessions with toddlers and preschoolers amid COVID-19: Implications for early childhood teacher education. Journal of Technology and Teacher Education, 28(2), 373-380.

Şahin, A. ve Atbaşı, Z. (2020). Olumlu okul iklimi oluşturmada öğretmenin rolünün incelenmesi. Ahi Evran Üniversitesi Sosyal Bilimler Enstitüsü Dergisi, 6(3), 672-689.

Trust, T. and Whalen J. (2020). Should teachers be trained in emergency remote teaching? Lessons learned from the COVID-19 pandemic. Journal of Technology and Teacher Education, 28(2), 189-199.

Tümkan, F. ve Tümkan, Ş. (2020). Pandemi döneminde eğitime verilen zorunlu aranın ilkokullardaki eğitim açısından yarattığı değişimin etkilerinin değerlendirilmesi. Electronic Turkish Studies, 15(4), 1163-1184. https://dx.doi.org/10.7827/TurkishStudies.44411

Tüysüz, C. ve Çümen, V. (2016). EBA ders web sitesine ilişkin ortaokul öğrencilerinin görüşleri. Uşak Üniversitesi Sosyal Bilimler Dergisi, 9(27/3), 278-296. 
Viner, R. M., Russell, S. J., Croker, H., Packer, J., Ward, J., Stansfield, C., Mytton, O., Bonell, C. and Booy, R. (2020). School closure and management practices during Coronavirus outbreaks including COVID-19: A rapid systematic review. The Lancet Child \& Adolescent Health, 4(3), 397-404. https://doi.org/10.1016/S2352-4642(20)30095-X

Yıldırım, A. ve Şimşek, H. (2018). Sosyal bilimlerde nitel araştırma yöntemleri. Ankara: Seçkin yayıncilik.

Woofter, S. (2019). Building equity: Policies and practices to empower all learners. American Journal of Qualitative Research, 3(1), 136-139. https://doi.org/10.29333/ajqr/5815 


\section{Extended Abstract}

\section{Introduction}

Almost all students who continue their education at all levels of education around the world experienced the temporary closure of schools during the New Coronavirus Disease (COVID-19) epidemic in order to reduce the transmission of the virus (Viner et al., 2020). According to the report published by United Nations Educational, Scientific and Cultural Organization (UNESCO, 2020) on the COVID-19 outbreak, schools have been closed in approximately 200 countries around the world, and more than $90 \%$ of the students have been interrupted in their formal education. Practices such as closing schools, distance education, controlled and systematic opening have taken their place among the measures taken within the scope of education in our country. Studies have shown that closing schools during epidemics have an effect on reducing contamination (Cowling et al., 2020; Nafisah, Alamery, Al Nafesa, Aleid and Brazanji, 2018).

School closures have caused students, their parents and teachers to change their daily lives in an unprecedented way. While more than half a billion children around the world remain at home and continue their distance education and become virtual students, their parents, siblings and other family members have turned into education coaches and assumed such a supportive role to ensure that their education lives are not negatively affected (Cohen and Kupferschmidt, 2020). Many teachers, families, and students were not prepared for this sudden change, and the increased parental involvement while trying to support their children's education in various ways has also created some difficulties and problems.

It is important to know the experiences of students and parents during the pandemic process, to organize distance education services to be offered and to prepare support projects for parents and students. Examining the roles of parents especially in the distance education process will contribute to both increasing the awareness of parents and increasing the quality of the education services provided. This study, it was aimed to examine the distance education experiences of parents during the pandemic process. For this purpose, the following questions were sought:

1. What are the parents' thoughts on the decision to close schools?

2. How do parents support their children within the scope of distance education?

3. What are the difficulties faced by parents within the scope of distance education?

4. What are the solution suggestions within the scope of eliminating the difficulties experienced by the parents?

5. What are the expectations of parents from teachers within the scope of distance education?

Although education continues remotely due to the pandemic, it is thought that parents will contribute significantly to creating a positive education environment at home. Teachers' role will be effective in creating this positive environment for parents. Şahin and Atbaşı (2020) emphasized the role of teachers in their studies in order to make educational environments effective. Regardless of the level of education, parents have requests for the support of teachers (Konca, 2020).

\section{Method}

The research was conducted to examine the distance education experiences of parents during the pandemic process. The research was created with a qualitative research design and was carried out using the interview technique. Twenty-one parents, whose children continue their primary education, participated in the study group of the research. Research data were obtained using a structured interview form. The data were analyzed using the descriptive analysis method.

Of the 21 parents who volunteered to participate in the interview, 17 are mothers and 4 are fathers. Each of these parents has different families, ie there are no parents who are spouses. 14 of the 
mothers are university graduates and 3 of them are high school graduates. All of the fathers are university graduates. The profession of 8 of the mothers is related to education. 1 class teacher, 2 kindergarten teachers, 1 art teacher and 4 education faculty lecturers/officers. None of the fathers' profession is related to education. 6 of the mothers have a single child, 11 of them have 2 children. 2 of the fathers have a single child, 1 of them has 2 children and 1 of them has 4 children. 1 child of 13 mothers and 2 children of 4 mothers attend school during the pandemic process. 1 child of 3 fathers and 4 children of 1 of them continue to school during the pandemic process. 16 of the mothers and all of the fathers have access to the internet when their schools are closed due to the pandemic.

\section{Findings}

According to the results, the majority of the parents participating in the research approve the decision to close the schools. They support their children for an average of 1-2 hours a day. They have sufficient educational resources. Satisfied or very satisfied with the support provided by the school during the closing process. They experience technical, social, student-centered, and education-centered difficulties in the distance education process. They want formal education and they think that teachers can be understanding and support the process.

\section{Conclusion, Discussion and Recommendations}

Protecting the health of their children and making them feel safe are among the primary duties of parents. In their research, Erol and Erol (2020) examined the effects of the pandemic process on primary school students, and found that both parents and children developed fear and anxiety due to the epidemic. While the children were more afraid of losing their parents due to illness, the parents revealed that they were concerned about the fear of contaminating their children from school and that the schools were not hygienic enough. Since COVID-19 is an easily transmissible disease, it is considered as an expected result for parents to act meticulously considering the health of their children, and to find the decision to close schools by thinking protective and caring.

The ages of students attending primary education generally vary between 6-11. In order for children of this age group to adapt to the distance education system, which they have never experienced before, in a short time, parents need to support their children. This support should be both technical and motivational.

It is very important to have sufficient educational resources for distance education in order to prevent the educational life of children from being negatively affected by the closure of schools. Parents need resources that their children can use while learning at home. Because, in addition to parenting responsibilities, they now also have educational responsibilities. For this reason, it is considered as an important result that parents do not experience resource problems.

It is thought that it is important to provide school-parent-teacher cooperation so that the educational life of children is not negatively affected by the process. 